\title{
Challenges and Opportunities of Cytochrome P450-Mediated Phytoremediation
}

\section{Santosh Kumar*}

School of Pharmacy, University of Missouri-Kansas City, USA

Although environmental pollution was first realized to be a threat to public health in the latter part of the $20^{\text {th }}$ century, events in the $21^{\text {st }}$ century have served to increase the public awareness of the impacts of environmental pollution. Several communities, including the scientific community initiated dialogues to help protect the planet from environmental pollution. Further, scientific community initiated basic and applied research in an effort to decontaminate soil, water, and air pollutions arising from industrial and petroleum wastes, as well as from the use of pesticides and herbicides. They utilized plant enzymes, as well as bacterial, fungal, and mammalian enzymes cloned in plants (transgenic plants), to detoxify soil and water contaminations (phytoremediation). Although there was a slow increase in research publications of phytoremediation from 1990-2000, a significant increase in their publications from 2001-2008 was observed (Figure 1). Interestingly, a decline in research publications since 2009 was observed, which suggests that there is a challenge in this type of research for further improvements in phytoremediation. A similar trend was also observed with cytochrome P450 (CYP)-mediated phytoremediation (Figure 1). In this editorial, we will discuss the challenges and opportunities of CYP-mediated phytoremediation. The discussion in this editorial is based on a recent review [1].

CYP family of enzymes involved in the metabolism and detoxification of numerous xenobiotics, including herbicides, pesticides, and industrial pollutants, such as pharmaceuticals, petrochemicals, polycyclic aromatic hydrocarbons (PAHs), and polychlorinated benzene (PCBs) [2]. The catalytic versatility of CYP enzymes have led to significant interest in utilizing them as biocatalysts

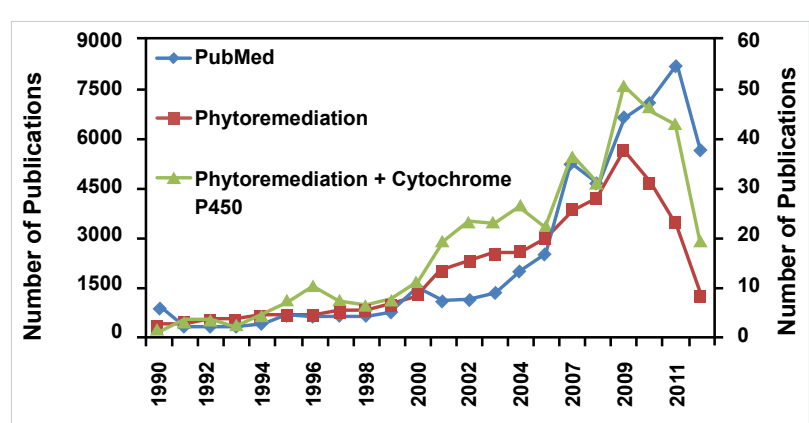

Publication years

Figure 1: Number of publications from 1990 to 2012 using the key words PubMed(control), phytoremediation, and phytoremediation+cytochrome P450 (CYP). Left Y-axis represents number of publications for PubMed and phytoremediation and right $\mathrm{Y}$-axis represents number of publications for phytoremediation + cytochrome P450. The control showed a slow increase in number of publications from 1990 to 2000, followed by a rapid increase in publications until 2011. Phytoremediation and CYP-mediated phytoremediation showed similar trend until 2009, however, there was a decline inthe number of publications from 2009 to 2011. As expected, all three showed less number of publications in 2012 (until August 15), however, the trends suggest that there would be a further increase in PubMed publications, but a decrease in the number of publications for phytoremediation and CYPbased phytoremediation. for phytoremediation. In the last decade there has been an increase in the utilization of CYP biocatalysts for creating herbicide-resistant plants and for the detoxification of soil and water contaminants. The use of transgenic plants expressing bacterial and mammalian CYP enzymes for phytoremediation is crucial because plant CYP enzymes are poor in detoxifying these contaminants [3], whereas bacterial and mammalian CYP enzymes have the capability to detoxify herbicides and industrial pollutants [4,5]. However, the major limitation of mammalian CYP enzymes is that they have relatively low turn-over, enzyme stability, and expression in plants. In contrast, many bacterial CYP enzymes display high levels of activity and stability; however, they metabolize limited number of pollutants. These are the major challenges in the utilization of CYP enzymes for phytoremediation that may have led to a decrease in research publications for CYP-mediated phytoremediation since 2009 (Figure 1). However, these challenges also bring an opportunity to expand innovative research towards engineering of CYP enzymes for the improvement of their substrate diversity, activity, stability, and expression in plants.

Since the beginning of $21^{\text {st }}$ century, significant progress has been made, especially by Arnold and colleagues, in designing bacterial CYP enzymes [6,7]. For example, a bacterial CYPBM3 enzyme has been engineered for novel activity towards hydroxylation of many non-natural alkanes, such as asoctane, hexane, propane, butane, and ethane, as well as other non-alkyl substrates, such as benzene, propylbenzene, and naphthalene. Similarly, another bacterial CYPCAM enzyme has been engineered for efficient oxidation of various alkanes (butane, pentane, hexane, and heptanes), halogenated hexanes, PCBs, and PAHs. These engineered CYPBM3 and CYPCAM enzymes can potentially be used to create transgenic plants for possible phytoremediation of these toxic compounds. Further, several mammalian CYP enzymes have been engineered to improve activity, stability, and heterologous expression [8]. For examples: 1) Guengerich and colleagues have successfully engineered human CYP2A6 enzyme for increased activity with indigo compounds and cloned it into tobacco plants that produced the precursor of indole dyes; 2) Kumar and Halpert groups have engineered Rat CYP2B1 and canine CYP2B11 enzymes for enhanced activity with several compounds, including anti-cancer prodrugs cyclophosphamide and ifosfamide; 3) Gillam and colleagues have designed CYP2C enzymes for novel activity with

*Corresponding author: Santosh Kumar, School of Pharmacy, University of MissouriKansas City, 2464 Charlotte St., Kansas City, MO 64108, Tel: 816-235-5494; Fax: 816-235-1776; E-mail: kumarsa@umkc.edu

Received August 17, 2012; Accepted August 17, 2012; Published August 25 , 2012

Citation: Kumar S (2012) Challenges and Opportunities of Cytochrome P450Mediated Phytoremediation. J Pet Environ Biotechnol S4:e001. doi:10.4172/2157 7463.S4-e001

Copyright: (C) 2012 Kumar S . This is an open-access article distributed under the terms of the Creative Commons Attribution License, which permits unrestricted use, distribution, and reproduction in any medium, provided the original author and source are credited. 
Citation: Kumar S (2012) Challenges and Opportunities of Cytochrome P450-Mediated Phytoremediation. J Pet Environ Biotechnol S4:e001. doi:10.4172/2157-7463.S4-e001

Page 2 of 2

6'-deoxyluciferin and diclofenac. Although these mammalian CYP enzymes were not engineered for enhanced activity with herbicides, industrial contaminants, or petroleum compounds, they provide a proof-of-concept that mammalian CYP enzymes can be engineered for phytoremediation of these compounds.

In conclusion, phytoremediation of soil and water contaminants arising from herbicides, pesticides, and industrial pollutants has been identified to be critically important to clean the environment and improve air and water qualities. Although generation of CYPbased transgenic plants has the potential to serve this purpose, certain limitations of CYP enzymes posed challenges in their application in phytoremediation. Thus, there is a critical need to expand the basic and applied research in designing CYP biocatalysts for phytoremediation and therefore additional effort is required from CYP enzyme and protein engineering communities towards this.

\section{Acknowledgement}

The author acknowledges financial support from NIH grant DA031616.

\section{References}

1. Kumar S, Jin M, Weemhoff JL (2012) Cytochrome P450-mediated phytoremediation using transgenic plants: A need for engineered cytochrome P450 enzymes. J Petrol Envir Biotechnol 3: 1-5.

2. Anzenbacher P, Anzenbacherová E (2001) Cytochromes P450 and metabolism of xenobiotics. Cell Mol Life Sci 58:737-747.

3. Morant M, Bak S, Møller BL, Werck-Reichhart D (2003) Plant cytochromes P450: tools for pharmacology, plant protection and phytoremediation. Curr Opin Biotechnol 14: 151-162.

4. Abhilash PC, Jamil S, Singh N (2009) Transgenic plants for enhanced biodegradation and phytoremediation of organic xenobiotics. Biotechnol Adv 27: 474-488.

5. Van Aken B (2009) Transgenic plants for enhanced phytoremediation of toxic explosives. Curr Opin Biotechnol 20: 231-236.

6. Whitehouse CJ, Bell SG, Wong LL (2012) P450 (BM3) (CYP102A1): connecting the dots. Chem Soc Rev 41: 1218-1260.

7. Jung ST, Lauchli R, Arnold FH (2011) Cytochrome P450: taming a wild type enzyme. Curr Opin Biotechnol 22: 809-817.

8. Kumar S (2010) Engineering cytochrome P450 biocatalysts for biotechnology, medicine and bioremediation. Expert Opin Drug MetabToxicol 6: 115-131. 